\title{
Atypical Lipomatous Tumor
}

National Cancer Institute

\section{Source}

National Cancer Institute. Atypical Lipomatous Tumor. NCI Thesaurus. Code C6505.

An intermediate, locally aggressive lipomatous neoplasm. Microscopically, the adipose tissue contains large and pleomorphic lipoblasts, and is dissected by fibrous septa containing spindle cells. It requires a wide local excision, may recur locally, but never metastasizes. 